\title{
24. COMPRESSIONAL WAVE VELOCITIES IN BASALT AND ALTERED BASALT RECOVERED DURING LEG 14
}

\author{
Paul J. Fox, E. Schreiber and J. Peterson, \\ Lamont-Doherty Geological Observatory of Columbia University, Palisades, New York
}

\section{INTRODUCTION}

The velocity of propagation of compressional waves was investigated in ten samples of basalt and altered basalt recovered during Leg 14 of the Deep Sea Drilling Project. Velocity measurements of the selected specimens were first conducted at atmospheric pressure and then at intervals of higher confining pressure up to 7 Kilobars. The velocity data presented here may provide useful criteria for the correlation of rock types cored at Sites 136, 137, 138, and 141 with seismic reflection, oblique reflection, and refraction profiles obtained from the eastern Atlantic.

\section{PROCEDURE}

Velocity measurements were performed using the modified pulse transmission method (Mattaboni and Schreiber, 1966) which is described in the Initial Reports of the Deep Sea Drilling Project, Volume XI, (Schreiber et al., 1972). The precision of our measurements is about 1 per cent because of hysteresis observed between measurements performed under increasing and decreasing confining pressure. The hysteresis is caused by anelastic changes that occur within the specimen, and these changes are attributed to adjustments in the pore and crack geometry during the application of pressure.

Specimens, one half inch in diameter, were cut from the drill cores in directions both parallel and perpendicular to the drilling axis in order to obtain information about possible velocity anisotrophy. The ends of the specimens were trimmed flat to produce surfaces that were parallel to within $0.002 \mathrm{~cm}$. The bulk density of each specimen was calculated on the basis of the dimensional measurements and its mass. Unless otherwise indicated, the error of the density measurements is \pm 1 per cent. Prior to measurement of the compressional wave velocities, the specimens were jacketed with 2 mil thick copper foil which prevented pressurizing fluid from penetrating into pores or cracks present in the specimen. Thus by jacketing the specimens, the contribution to the change in velocity as cracks and pores close under increasing pressure, could be determined. Specimens were measured in the "as received" condition and were neither dried nor saturated prior to the velocity measurements.

\section{RESULTS}

Basaltic rock was recovered at the bottom of Site 136 in the abyssal hill province $150 \mathrm{~km}$ north of Madeira. The basalt was cored 308 meters below the sediment-water interface, a depth which correlates well with the calculated

\footnotetext{
${ }^{1}$ Lamont-Doherty Geological Observatory of Columbia University, Contribution No. 1791.
}

depth of the basement reflector. The petrology of the basaltic samples has been analyzed (see Chapter 23), and the results show that the recovered specimen is an intergranular to subophitic basalt composed of plagioclase, pyroxene, and minor opaque oxides set in an altered microcrystalline groundmass composed of serpentine, chlorite, and other low temperature alteration products. The measured velocities of the two specimens ranged from $3.87-3.89 \mathrm{~km} / \mathrm{sec}$ at $.25 \mathrm{~Kb}$ to $4.66-4.69 \mathrm{~km} / \mathrm{sec}$ at $7.0 \mathrm{~Kb}$ (Table 1).

At Site 137, which is located $1000 \mathrm{~km}$ west of Cape Blanc in the abyssal hill province, altered basaltic rock was recovered 397 meters below the sediment-water interface. Petrological analyses of the recovered rocks (see Chapter 23) indicate that the samples are deeply altered basalt. Relict phenocrysts of plagioclase and minor augite are set in a matrix of low temperature alteration products (zeolite, chlorite, albite, and saussurite). Veins of calcite and serpentine cut the altered basalt. The velocities of the two specimens measured ranged from $3.43-3.46 \mathrm{~km} / \mathrm{sec}$ at .25 $\mathrm{Kb}$ to $4.19-4.20 \mathrm{~km} / \mathrm{sec}$ at $7.0 \mathrm{~Kb}$ (Table 1 ).

At Site 138, which lies $130 \mathrm{~km}$ east of Site 137 at the foot of the West African Continental Rise, altered basalt was recovered $437 \mathrm{~m}$ below the sediment-water interface at the bottom of the hole. Petrographic analyses (see Chapter 23 ) indicate that the rock is an altered, inter-granular basalt composed of: plagioclase which often has been altered to epidote, clinozoisite, calcite, albite, and natrolite; pyroxene which has been replaced by chlorite, biotite, and hornblende; and matrix material which originally may have been glass but is now composed of chlorite and zeolite. The compressional wave velocities of four samples, two from the upper section of cored basalt and two from the lower section, were measured. At .25 Kilobar confining pressure the velocity ranged from $3.40-4.54 \mathrm{~km} / \mathrm{sec}$, and at 7.0 Kilobars the velocity ranged from $4.16 \mathrm{~km} / \mathrm{sec}-5.19 \mathrm{~km} / \mathrm{sec}$ (Table 1). The velocities of three of the four samples were similar $( \pm .2 \mathrm{~km} / \mathrm{sec})$ at all confining pressures. The fourth sample has measured velocities $1 \mathrm{~km} / \mathrm{sec}$ lower than the other three. This particular sample is cut by numerous zeolite veins, and the lower measured velocities are attributed to the veining rather than structural or mineralogical anisotrophy. The three other samples are devoid of veining.

At Site 141, located about $200 \mathrm{~km}$ north of the Cape Verde Islands, basaltic rock was sampled $295 \mathrm{~m}$ below the sediment-water interface. Petrographic analyses (see Chapter 23) show that the basaltic rock has been severely altered although the original sub-ophitic to intersertal texture is preserved in many areas. The sample consists of varying amounts of chlorite, serpentine group minerals, and relict laths of labradorite which have often been completely 
saussuritized and albitized. Although much of the recovered rock is veined by serpentine and calcite, the two specimens analyzed during this study are devoid of veining. The measured velocity of the two specimens ranged from $3.70-3.73 \mathrm{~km} / \mathrm{sec}$ at $.25 \mathrm{~Kb}$ to $4.69-4.73 \mathrm{~km} / \mathrm{sec}$ at $7.0 \mathrm{~Kb}$ (Table 1).

\section{DISCUSSION}

The velocities measured for these samples are, in general, lower by about $1 \mathrm{~km} / \mathrm{sec}$ than velocities measured for basement samples recovered off the east coast of the United States during Leg 11 of the Deep Sea Drilling Project (Schreiber et al., 1972). Also, the velocities measured for the Leg 14 basaltic samples are $1.0-1.5 \mathrm{~km} / \mathrm{sec}$ lower than the velocities measured for basaltic rocks dredged from the ocean floor (Christensen, 1970; Christensen and Shaw, 1970; Barrett and Aumento, 1971; and Fox et al., 1971). Most of the oceanic basalt samples reported on by other investigators are relatively fresh and unaltered. The basaltic basement samples recovered during Leg 14 have all experienced varying degrees of low-grade secondary hydrothermal alterations thus suggesting that the development of chlorite, serpentine, and other alteration products, at the expense of primary mafic minerals and glass, lowers the compressional wave velocity of the basaltic sample.

The compressional wave velocities determined for basement (Layer 2) over the Mid-Oceanic Ridge and ocean basins, range from $3.7-6.0 \mathrm{~km} / \mathrm{sec}$ with the majority of these measurements falling between 4.4-5.6 km/sec (Raitt, 1963). The calculated in situ lithostatic pressure range for the basaltic specimens sampled during Leg 14 is $.25-.50 \mathrm{~Kb}$. At these pressures our samples ranged in velocity from 3.40 to $4.59 \mathrm{~km} / \mathrm{sec}$ (see Table 1). All but two samples, however, have velocities lower than $4.5 \mathrm{~km} / \mathrm{sec}$ at these confining pressures, and compressional wave velocities in this range are not typical of the velocities normally recorded for oceanic basement (Layer 2). During a study of the compressional-wave velocities of basalts from the Juan de Fuca Ridge, Christensen (1960) reported that water saturation of a fresh, unaltered basaltic sample at confining pressures below $1 \mathrm{~Kb}$ increased the velocity of the basalt specimen by approximately 25 per cent. It is possible that the specimens of oceanic rocks sampled during Leg 14 contained more pore water in situ than the specimens do presently. Therefore, based on Christensen's result, the measured laboratory velocities of the Leg 14 specimens could be as much as $.5-.8 \mathrm{~km} / \mathrm{sec}$ lower than the in situ velocity of these rocks due to a decrease in pore water. Several sonobuoy stations in the area of Sites 137, 138 and 141 , however, record oceanic basement (Layer 2) velocities in the $4.0-4.5 \mathrm{~km} / \mathrm{sec}$ range (Houtz, personal communication). These recorded sonobuoy velocities fall within the range of velocities which we measured for the basaltic samples recovered during DSDP Leg 14. On the basis of the agreement between our laboratory data and velocities derived from the sonobuoy data, we assume that no significant amount of pore water was present in the rock in situ, and, consequently, we conclude that the oceanic basement in the area of the drill-sites off the West African margin is composed of basaltic rocks which have experienced regional low temperature alteration.

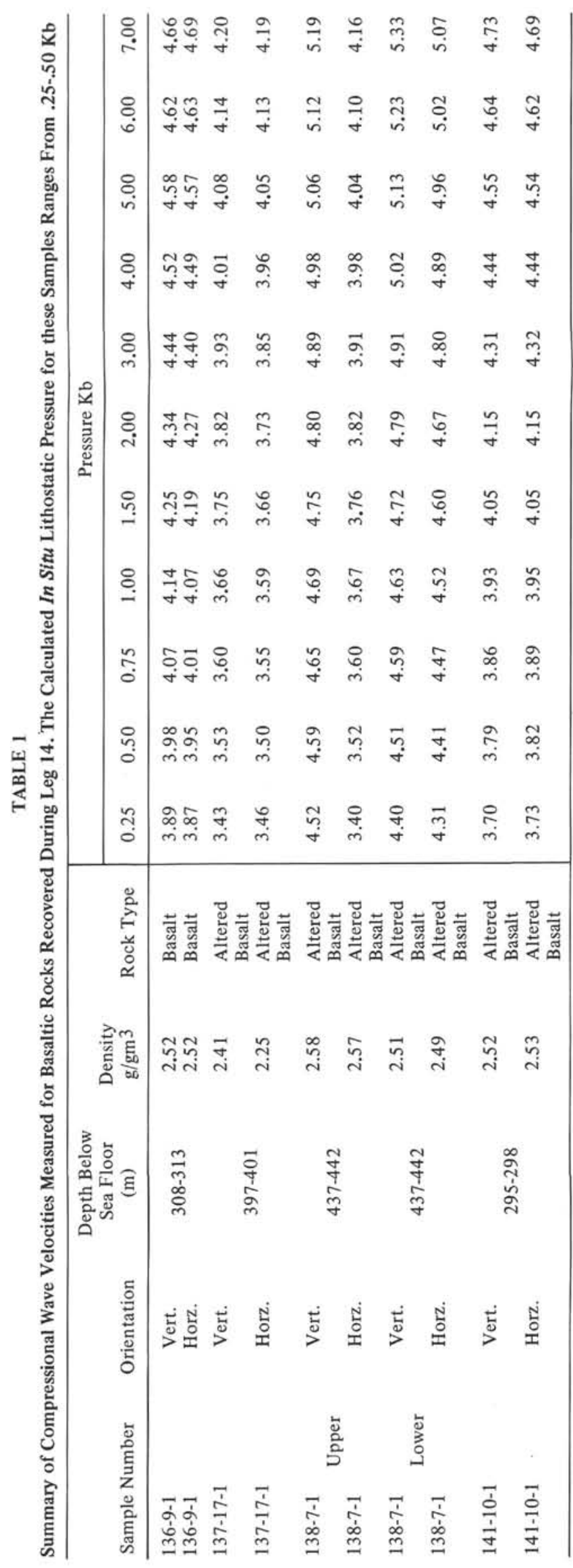




\section{ACKNOWLEDGMENTS}

The authors wish to express their appreciation to D. Hayes for providing them with the opportunity to study specimens of Leg 14. Support for this research came from National Science Foundation grants GA 30618 (E. S. and P. J. F.), GA 27281 (P. J. F.), and Office of Naval Research grant TO4-N00014-67-A-0108-0004 (P. J. F.).

\section{REFERENCES}

Barrett, D. L. and Aumento, F., 1971. The Mid-Atlantic Ridge near $75^{\circ}$ N. XI. Seismic velocity, density and layering of the crust. Can. J. Earth Sci. 7, 1117-1124.

Christensen, N. I., 1970. Compressional wave velocities in basalts from the Juan de Fuca Ridge. J. Geophys. Res. $75,2773-2775$.
Christensen, N. I. and Shaw, C. M., 1970. Elasticity of mafic rocks from the Mid-Atlantic Ridge. Geophys. J. Roy. Astron. Soc. 20, 271-284.

Fox, P. J., Peterson, J. J. and Schreiber, E., 1971. Compressional wave velocity characteristics of oceanic rocks. Abstracts with programs. Geol. Soc. A. 3, no. 7, 572.

Mattaboni, P. and Schreiber, E., 1967. Method of pulse transmission measurements for determining sound velocities. J. Geophys. Res. 72, 5160-5163.

Raitt, R. W., 1963. The crustal rocks, In, Hill, M. N., Editor, The Sea. John Wiley. Interscience, New York, 3, 85-100.

Schreiber, E., Fox, P. J. and Peterson, J. J., 1972. Compressional sound velocities in semi-indurated sediments and basalts. From Deep-Sea Drilling Project, Leg 11, In Initial reports of Deep-Sea Drilling Project, Volume XI. Washington (U.S. Government Printing Office). In press. 